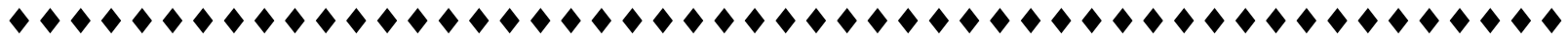
DOI: 10.46666/2020. 2708-9991.22

МРНТИ06.71.07

УДК 338.43

https://agroeconom.kz

ПЛОДООВОЩНАЯ ОТРАСЛЬ ЮЖНО-КАЗАХСТАНСКОГО РЕГИОНА: СОСТОЯНИЕ И ПЕРСПЕКТИВЫ

ОНТҮСТІК ҚАЗАҚСТАН ОБЛЫСЫНЫҢ ЖЕМІС-КӨКӨНІС САЛАСЫ: ЖАҒДАЙЫ ЖӘНЕ БОЛАШАҒЫ

\title{
FRUIT AND VEGETABLE INDUSTRY OF THE SOUTH KAZAKHSTAN REGION: STATE AND PROSPECTS
}

\author{
Е.Е. ГРИДНЕВА* \\ К.э.Н., доцент \\ Г.Ш. КАЛИАКПАРОВА \\ доктор $P h D$ \\ H.М. КАЛМАНОВА \\ магистр экономики и бизнеса \\ Академия «Кайнар», Алматы, Казахстан \\ *elengred@mail.ru \\ Е.Е. ГРИДНЕВА \\ Э.Ғ.К., доцент \\ Г.Ш. ҚАЛИАҚПАРОВА \\ PhD докторы \\ Н.М. КАЛМАНОВА \\ экономика және бизнес магистрі \\ «Қайнар» академиясы, Алматы, Қазақстан \\ Y.E. GRIDNEVA \\ C.E.Sc., Associated Professor \\ G.SH. KALIAKPAROVA \\ PhD \\ N.M. KALMANOVA \\ Master of Economics and Business \\ Academy "Kainar", Almaty, Kazakhstan
}

\begin{abstract}
Аннотация. Авторами изучены возможности и перспективы развития плодоовощной отрасли Южно-Казахстанского региона. Одной из приоритетных отраслей пищевой промышленности является плодоовощной сектор. В статье рассматриваются актуальные вопросы повышения эффективности функционирования плодоовощного производства, решение которых имеет важное значение для обеспечения продовольственной безопасности страны, так как благодаря высокой биологической ценности овощи и фрукты занимают особое место в сбалансированном и витаминизированном питании населения. Отмечается научная и практическая значимость перспективы расширения объемов выработки плодоовощной продукции. Представлены рекомендации по переходу на индустриально-инновационный путь, высокий уровень конкурентоспособности переработки собственных плодоовощных продуктов. Дана оценка степени и условий инновационного развития в Южно-Казахстанском регионе (Алматинская, Туркестанская, Жамбылская, Кызылординская области). Определен потенциал выращивания плодоовощных культур. Отражены аспекты современного состояния производства, хранения, переработки и сбыта группы плодоовощных товаров в Южном Казахстане. Проанализированы направления инновационной деятельности в плодоовощном подкомплексе. Обоснована необходимость государственного регулирования и стимулирования производства плодоовощной продукции. В современных условиях наиболее перспективным направлением экономического роста региона является организация плодоовощных кластеров. Показаны основные направления дальнейшего развития плодоовощного производства Южного региона для более полного использования его потенциальных возможностей, расширения эффективной эксплуатации природных и экономических ресурсов: земли, атмосферных факторов, оросительной воды, кооперации, концентрации капитала, новой техники и технологий, обеспечения региона продовольствием и активизации экспорта в страны дальнего и ближнего зарубежья.
\end{abstract}




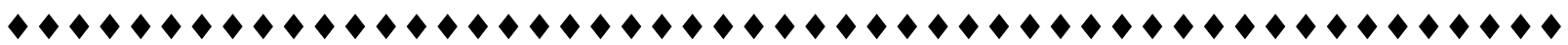

Аңдатпа. Авторлар Оңтүстік Қазақстан өңірінің жеміс-көкөніс саласын дамытудың мүмкіндіктері мен перспективаларын зерттеді. Тамақ өнеркәсібінің басым салаларының бірі Жеміскөкөніс секторы болып табылады. Мақалада жеміс-көкөніс өндірісінің тиімділігін арттырудың өзекті мәселелері қарастырылады, оларды шешу елдің азық-түлік қауіпсіздігін қамтамасыз ету үшін маңызды, өйткені жоғары биологиялық құндылықтың арқасында көкөністер мен жемістер халықтың теңдестірілген және байытылған тамақтануында ерекше орын алады. Жеміс-көкөніс өнімдерін өндіру көлемін кеңейту перспективасының ғылыми және практикалық маңыздылығы атап өтілді. Индустриялық-инновациялық жолға көшу, жеке жеміс-көкөніс өнімдерін қайта өңдеудің бәсекеге қабілеттілігінің жоғары деңгейі бойынша ұсынымдар ұсынылды. Оңтүстік Қазақстан өңіріндегі (Алматы, Түркістан, Жамбыл, Қызылорда облыстары) инновациялық даму дәрежесі мен шарттарына баға берілді. Жеміс-көкөніс дақылдарын өсіру әлеуеті анықталды. Оңтүстік Қазақстандағы жеміс-көкөніс тауарлары тобын өндірудің, сақтаудың, қайта өңдеудің және өткізудің қазіргі жай-күйінің аспектілері көрсетілген. Жеміскөкөніс қосалқы кешеніндегі инновациялық қызмет бағыттары талданған. Жеміс-көкөніс өнімдерін өндіруді мемлекеттік реттеу және ынталандыру қажеттілігі негізделген. Қазіргі жағдайда өңірдің экономикалық өсуінің неғұрлым перспективалы бағыты жеміс-көкөніс кластерлерін ұйымдастыру болып табылады. Оның әлеуетті мүмкіндіктерін барынша толық пайдалану, табиғи және экономикалық ресурстарды: жерді, атмосфералық факторларды, суармалы суды, кооперацияны, капиталды шоғырландыруды, жаңа техника мен технологияларды тиімді пайдалануды кеңейту, өңірді азық-түлікпен қамтамасыз ету және алыс және жақын шетелдерге экспортты жандандыру үшін оңтүстік өңірдің жеміс-көкөніс өндірісін одан әрі дамытудың негізгі бағыттары көрсетілген.

Abstract. The authors studied the possibilities and prospects for the development of fruit and vegetable industry of the South Kazakhstan region. One of the priority sectors of food industry is the fruit and vegetable sector. The article discusses topical issues of increasing the efficiency of functioning of fruit and vegetable production, the solution of which is important for ensuring the food security of the country, since due to the high biological value, vegetables and fruits occupy a special place in the balanced and fortified nutrition of the population. The scientific and practical significance of the prospects for expanding the volume of fruit and vegetable production is noted. Recommendations for the transition to industrial-innovative way, high level of competitiveness of processing of own fruit and vegetable products are presented. The assessment of the degree and conditions of innovative development in the South Kazakhstan region (Almaty, Turkestan, Zhambyl, Kyzylorda regions) is presented. The potential for growing fruit and vegetable crops has been determined. The aspects of the current state of production, storage, processing and marketing of a group of fruits and vegetables in South Kazakhstan are reflected. The directions of innovative activity in the fruit and vegetable subcomplex are analyzed. The necessity of state regulation and stimulation of production of fruits and vegetables has been substantiated. In modern conditions, the most promising area of economic growth in the region is organization of fruit and vegetable clusters. The main directions of further development of fruit and vegetable production in the Southern region are shown for a fuller use of its potential opportunities, expansion of the effective exploitation of natural and economic resources: land, atmospheric factors, irrigation water, cooperation, concentration of capital, new equipment and technologies, provision of the region with food and activation of exports to CIS and foreign countries.

Ключевые слова: Южно-Казахстанский регион, природные ресурсы, плодоовощная отрасль, производство, инновационное развитие, рентабельность, кластеры, модернизация производства, новаторство, конкурентоспособность.

Түйінді сөздер: Оңтүстік Қазақстан өңірі, табиғи ресурстар, жеміс-көкөніс саласы, өндіріс, инновациялық даму, рентабельділік, кластерлер, өндірісті жаңғырту, жаңашылдық, бәсекеге қабілеттілік.

Key words: South Kazakhstan region, natural resources, fruit and vegetable industry, production, innovative development, profitability, clusters, production modernization, innovation, competitiveness.

Введение. Одной из важнейших отраслей агропромышленного комплекса является плодоовощное производство, связанное с заготовкой, обработкой, хранением, переработкой, реализацией и транс- портировкой плодоовощной продукции. Даннная отрасль имеет большой потенциал для инновационного развития. Инновации - основной инструмент конкуренции, поскольку инновационные услуги позволя- 


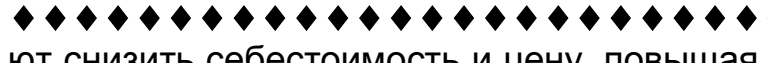

ют снизить себестоимость и цену, повышая прибыль и спрос на плодовощную продукции, престиж производителей, которые находят новые рынки сбыта. Слабая инновационная деятельность или ее отсутствие на отечественых предприятиях выявляет ряд проблем.

Одной из проблем, сдерживающих развитие системы производства, хранения, переработки и сбыта плодоовощной продукции, являются противоречия в стоимостных взаимоотношениях между сельскохозяйственными производителями, хранилищными, перерабатывающими и торгово-сбытовыми предприятиями, что оборачивается неэквивалентным получением прибыли за единицу затрат конечной продукции. Отсутствие необходимой инфраструктуры, неорганизованность сбыта плодоовощной продукции приводят к росту ввоза импортной продукции и низкой конкурентоспособности отечественной продукции.

Для устранения данных проблем необходима разработка основных направлений экономического и организационного перевода на индустриально-инновационное развитие плодоовощного производства ЮжноКазахстанского региона. А для эффективного управления и инновационного развития плодовоовощного сектора - формирование плодоовощных кластеров в регионе.

Материал и методы исследования. Теоретической и методологической базой исследования являются труды отечественных и зарубежных ученых в области устойчивого развития плодовоовощного производства, исследование которого базируется на системе представлений его генезиса и особенностей.

При проведении данных исследований авторы опирались на различные методы экономического анализа.

Экономико-статистический метод применялся при оценке современного состояния, потенциала перерабатывающих предприятий на примере Южно-Казахстанского региона. С помощью абстрактно-логического метода были проанализированы большой объем литературных источников, исследованы организационные и технологические вопросы развития плодового подкомплекса.

Такие общенаучные методы, как анализ, абстрагирование, обобщение и т.д. помогли выявить недочеты и перспективы эффективного развития через использование инновационных техники и технологий, сохранение плодородия почв, восстановление питомниководства, строительство современных хранилищ и перерабатывающих предприятий с высокотехнологичным и ресурсосберегающим оборудованием, решение вопросов финансирования и государственной поддержки.

Аналитическая часть работы выполнена на основе данных Комитета по статистике Министерства национальной экономики Республики Казахстан.

Результаты и их обсуждение. Анализ современного состояния плодоовощных культур Казахстана свидетельствует о значительной доле южного региона (Алматинской, Туркестанской, Жамбылской, Кзылординской областей), это связано с подходящими почвенно-климатическими условиями. В Южно-Казахстанском регионе объем производства овощей составляет $69,9 \%$ общего объема производства по республике. Доля Алматинской области составляет 923,8 т (27\%), Туркестанской 747,6 т (21,9 б\%), Жамбылской 643,4 т (18,8\%), Кызылординской 72,8 т (2,1\%). Производство бахчевых культур в южном регионе республики занимает $89,4 \%$, распределилось следующим образом: Алматинской - 106,2 т (5,1\%), на долю Туркестанской области - 1383,3т (66,3\%), Жамбылской - 259,8 т (12,4\%), Кызылординской - 116,9 т (5,6\%) общего объема производства [1]. При этом производство плодоовощной продукции не покрывает потребностей населения.

Согласно рекомендациям Всемирной организации здравоохранения для надлежащего поступления в организм клетчатки и предотвращения хронических заболеваний, таких как инфаркт, рак, диабет и ожирение, необходимо доводить потребление овощей и фруктов как минимум до 400 граммов в сутки, что также способствует снижению риска заражения неинфекционными заболеваниями. Что же касается годовой потребности человека в овощных и бахчевых культурах, то этот показатель составляет порядка 143 кг/год. Ученые из Германского общества питания считают, что оптимальная норма потребления свежих овощей и фруктов на одного человека должна составлять: 146 кг/г - овощей и 91 кг/г - фруктов. В Украине потребляют 163 кг овощей и бахчевых культур на человека, а жители России - 79 кг при норме от 120140 килограмм. В Республике Беларусь этот показатель равен 135 кг на одного жителя страны [2].

Под производство картофреля в Казахстане ежегодно отводится более 200 тыс. га земли. При средней урожайности 20-25 т с га ежегодно выращивается более 2 млн 


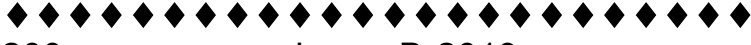

200 тыс. т картофеля. В 2019г. под овощебахчевые культуры и картофель было выделено 458,3 тыс. га земли [3]. По медицинским нормам на одного человека в год необходимо потребление 100 кг картофеля. В стране с населением на 2020г. около 19 млн человек [4] нам необходимо производить 1,9 млн т, плюс ежегодно семян 900-1000 тыс. тонн.

Под овощные культуры отводится 110115 тыс. га ежегодно, под бахчевые-более 50 тыс. гектаров. Согласно медицинским нормам необходимое потребление овощей в год - 120-130 кг на 1 человека, фрруктов 120 кг, бахчевых - 23 кг. Значит, по этим показателям мы должны производить около 3,5 млн т этой продукции. По статистическим данным, республика обеспечивает себя этой продукцией и даже какие-то виды экспортирует, например, лук в Россию [5]. Следует отметить, что производство овощной продукции имеет сезонность. Проведя анализ цен на рынке, мы видим, что цены падают осенью, а зимой и весной наблюдается их нестабильность. Осенью 2019г. фермеры Алматинской области сдавали капусту оптом по 20-35 тг за 1 кг, морковь по 30-40 тенге.

В 2018г. потребление фруктов в среднем на душу населения составило 77,9 кг, 2019г. - 77,4 кг, что на 0,64\% ниже. В тоже время наблюдается снижение потребления овощей на 7,97\%: 2018г. - 94,1 кг и 2019г. - 86,6 килограмм [5].

Следует обратить внимание на одну из острых проблем - это нехватка или отсутствие овощехранилищ в отдельных районах Южно-Казахстанского региона. Значительная часть хранилищ не соответствует современным требованиям (более $80 \%$ построенные или реконструированные ранее 2000г.) и требуют капитального ремонта из-за изношенности оборудования и зданий, поэтому здесь преобладает при сортировке овощей и фруктов ручной труд. Большая часть действующих овощехранилищ не оснащены холодильным оборудованием, что ведет к потере товарных качеств продукта. Наполняемость хранилищ, используемых по прямому назначению, не превышает 85\%. В действующих хранилищах хранится преимущественно общераспространенная сельскохозяйственная продукция, выращиваемая в Казахстане: картофель, лук, капуста, морковь, свекла.

Значительная доля производственных мощностей плодоовощеконсервных предприятий республики по готовой продукции приходится на Алматинскую область и Ал- маты - 70,2\%, Туркестанскую - 27,7\%, Жамбылскую - 2,0\% [6]. В производстве переработанной плодоовощной продукции доля производственных мощностей по отдельным видам консервированной продукции распределилась следующим образом: в Алматинской области доля мощностей по производству овощных консервов составляет $75,3 \%$ от общего областного показателя, фрруктовых - 0,1, томатных - 59,5\%, в Жамбылской - овощных консервов $42,8 \%$, фрруктовых - 0,1, томатных - 24,5\%, Туркестанской - овощных - 67,6\%, фрруктовых $-2,9$, томатных $-29,5 \%$.

В республике общая картина по переработке плодоовощной продукции представлена следующим образом: почти не производятся фрруктовые консервы, лидирует только переработка овощей, так доля консервированной овощной продукции составляет $55,5 \%$, фруктовой - $1,1 \%$, томатной $-43,4 \%$ [5].

В настоящее время наблюдается отставание в производстве плодоовощных культур. Более половины затрат в отрасли приходится на ручную уборку урожая. Для того чтобы внедрить новаторские решения, необходимы благоприятные экономические условия, последовательно объединяющие элементы инновационного механизма, а также поиск новых форм интеграции производства и науки. На наш взгляд, для эффективного управления и инновационного развития плодовоовощного производства необходимо формирование плодоовощных кластеров в Южно-Казахстанском регионе.

Плодоовощной кластер - это территориально-отраслевое добровольное объединение предприятий, производящих плодоовощную продукцию, по переработке плодоовощного сырья, сотрудничающих с финансовыми, научными, учебными учреждениями, органами местной власти с целью улучшения конкурентоспособности собственной продукции и эффрективного экономического роста региона.

Преимуществом плодоовощного кластера является эффект охвата, возможность использовать многофункциональный фактор на различных предприятиях при минимизации транзакционных издержек, связанных с его передачей [7]. Цель плодоовощного кластера - развитие группы предприятий, создающих взаимовыгодную продукцию, связанных между собой кооперативными связями. Задачей плодоовощного кластера является объединение вокруг плодоовощного сектора регионального бизнеса. Крупные компании по производству и переработке осуществляют роль яд- 
$\bullet \bullet \bullet \bullet \bullet \bullet \bullet \bullet \bullet \bullet \bullet \bullet \bullet \bullet \bullet \bullet \bullet \bullet \bullet \bullet \bullet$

ра кластера, а малый и средний бизнес (сорера услуг), который развивается вокруг них, становится важным плательщиком в бюджет и значительным источником экономического роста региона.

Создание кластера в южном регионе должно привести к следующим выгодам: стимулирование подходов к научным разработкам, развитие конкуренции, создание условий для активизации инновационной деятельности, оказание помощи друг другу участниками кластера, объединение усилий государственно-частного партнерства, привлечение инвестиций, развитие инфраструктуры, решение острых социальных проблем региона и многое другое.

Следует отметить, что в 2005-2010гг. была осуществлена попытка формирования пилотного плодоовощного кластера в Алматинской, Жамбылской, Южно-Казахстанской областях, но данный проект не реализовался на практике. С 2017г. действует план мероприятий по созданию пилотного проекта в Шуском районе Жамбылской области плодоовощного кластера. Организационно-экономическими предпосылками формирования овощного кластера в Шуском районе Жамбылской области стали [8]:

- производство овощей, превышающее медицинские нормы потребления (179 тыс. т овощей, 22,4 тыс. т картофеля, 165 тыс. т бахчевых при численности населения 98 тыс. человек);

- потенциал расширения посевных площадей под овощными и бахчевыми культурами, проводимая в районе диверси- фикация посевных площадей зерновых, их сокращение с 7,3 до 0,7 тыс.га за счет расширения площадей овощных культур с 1 до 4,5 тыс.га и бахчевых - с 2 до 4,5 тыс.га;

- расширение площадей орошаемых земель до 9,4 тыс. га, в том числе под овощными культурами - до 5,2 тыс. га;

- наличие высокого потенциала трудовых ресурсов, особенно сельского, доля которого составляет $64,3 \%$ от общей численности населения;

- необходимость объединения малых форм хозяйствования в более крупные хозяйства (доля крестьянских хозяйств, занятых овощеводством составляет $65,5 \%$ или 4661 га, доля ЛПХ соответственно 28\% (1969 га);

- необходимость организованного цивилизованного сбыта овощной продукции путем развития системы хранения, переработки и реализации.

На первом этапе развития проекта было вложено 7,2 млрд. тенге. На втором этапе (2020-2021гг.) предполагается вложить 39,2 млрд. тенге [9].

Рассмотрим потенциальные возможности южных регионов Казахстана имеющим площади посева под овощами 139 тыс. га (в том числе Жамбылская область 26,1 Алматинская - 31,6, Южно-Казахстанская - 36,5 тыс. га), из них площади, вовлеченные при формировании овощного кластера составляют 16,7 тыс. га, (в том числе Жамбылской области - 5,2 тыс. га, Алматинской - 5,5 тыс. га, Южно-Казахстанской -6 тыс. га) (таблица 1).

Таблица 1 - Посевные площади овощных культур в условиях формирования отраслевого кластера в южном регионе Казахстана

\begin{tabular}{|c|c|c|c|c|c|c|}
\hline \multirow[b]{2}{*}{ Область } & \multicolumn{3}{|c|}{$\begin{array}{c}\text { Посевные площади в разрезе } \\
\text { категорий хозяйств, тыс.га }\end{array}$} & \multirow{2}{*}{$\begin{array}{c}\text { Всего посе- } \\
\text { вов во всех } \\
\text { категориях } \\
\text { хозяйств, } \\
\text { тыс.га }\end{array}$} & \multirow{2}{*}{$\begin{array}{l}\text { В том чис- } \\
\text { ле площа- } \\
\text { ди, вовле- } \\
\text { чен-ные в } \\
\text { овощной } \\
\text { кластер, } \\
\text { тыс.га }\end{array}$} & \multirow{2}{*}{$\begin{array}{c}\text { Удельный } \\
\text { вес доли } \\
\text { площадей } \\
\text { овощного } \\
\text { кластера, в } \\
\% \text { от общей } \\
\text { площади }\end{array}$} \\
\hline & $\begin{array}{c}\text { сельхоз- } \\
\text { предпри- } \\
\text { ятия }\end{array}$ & $\begin{array}{c}\text { кре- } \\
\text { стьян- } \\
\text { ские } \\
\text { хозяй- } \\
\text { ства }\end{array}$ & $\begin{array}{c}\text { хозяй- } \\
\text { ства } \\
\text { населе- } \\
\text { ния }\end{array}$ & & & \\
\hline Алматинская & 2,3 & 17,4 & 11,9 & 31,6 & 5,5 & 17,4 \\
\hline Жамбылская & 1,6 & 17,1 & 7,4 & 26,1 & 5,2 & 19,9 \\
\hline Южно-Казахстанская & 2,7 & 21,2 & 12,6 & 36,5 & 6,0 & 16,4 \\
\hline Остальные области & 1,6 & 11,7 & 31,5 & 44,8 & - & 3 \\
\hline Всего по Казахстану & 8,2 & 67,4 & 63,4 & 139,0 & 16,7 & 12,0 \\
\hline
\end{tabular}

При условии формирования отраслевого кластера в южном регионе Казахстана спрогнозируем производство овощей на 2020-2021гг., которое рассчитано с учетом использования прогрессивных технологий выращивания овощей, капельного ороше- ния и др., что предусматривает повышение урожайности более чем в 2 раза (в среднем по РК - 291 ц/га) [10]. За счет развития кластера производство овощей к 20202021гг. может достигнуть показателя 4601,8 тыс. т, в том числе 1048,7 тыс. т в 
хозяйствах, входящих в отраслевой кла- | стер (таблица 2).

Таблица 2 - Прогноз производства овощных культур на 2020-2021гг. в условиях формирования отраслевого кластера в Южном регионе Казахстана

\begin{tabular}{|c|c|c|c|c|c|c|}
\hline \multirow{3}{*}{ Область } & \multirow{3}{*}{$\begin{array}{c}\text { Производ- } \\
\text { ство ово- } \\
\text { щей, все- } \\
\text { го, тыс. } \\
\text { тонн }\end{array}$} & \multicolumn{5}{|c|}{ Из них } \\
\hline & & \multirow[b]{2}{*}{$\begin{array}{c}\text { в хозяйст- } \\
\text { вах, входя- } \\
\text { щих в от- } \\
\text { раслевой } \\
\text { кластер, } \\
\text { тыс.т }\end{array}$} & \multirow[b]{2}{*}{$\begin{array}{c}\text { \% об- } \\
\text { щего } \\
\text { произ- } \\
\text { вод- } \\
\text { ства }\end{array}$} & \multirow[b]{2}{*}{$\begin{array}{c}\text { в остальных } \\
\text { хозяйствах, } \\
\text { не входящих } \\
\text { в отрасле- } \\
\text { вой кластер, } \\
\text { тыс.т }\end{array}$} & \multicolumn{2}{|c|}{ Из них } \\
\hline & & & & & $\begin{array}{c}\text { крестьян- } \\
\text { ские хо- } \\
\text { зяйства, } \\
\text { тыс. т }\end{array}$ & $\begin{array}{c}\text { хозяй- } \\
\text { ства } \\
\text { населе- } \\
\text { ния, } \\
\text { тыс.т }\end{array}$ \\
\hline Алматинская & 1104,9 & 345,4 & 31,2 & 759,5 & 255,9 & 503,6 \\
\hline Жамбылская & 934,7 & 326,5 & 34,9 & 608,2 & 286,4 & 321,8 \\
\hline Южно-Казахстанская & 1264,3 & 376,8 & 29,8 & 887,5 & 307,9 & 579,6 \\
\hline Остальные области & 1297,9 & - & - & 1297,9 & 233,6 & 1064,3 \\
\hline Всего по Казахстану & 4601,8 & 1048,7 & 22,8 & 3553,1 & 1083,8 & 2469,3 \\
\hline
\end{tabular}

Рост инновационной активности плодоовощных хозяйств на основе кластера способствует повышению конкурентоспособности, внедрению инновационных услуг в плодоовощном комплексе, расширению внутреннего рынка, повышению потенциала экспорта и импортозамещения, доли пищевой промышленности в национальной экономике [11].

\section{Заключение}

1. Плодоовощной сектор страны содержит ряд проблем, сдерживающих его развитие, выделим часть из них: усиление конкуренции со стороны дальнего и ближнего зарубежья; слабо развитые инфраструктура по переработке овощных культур и уровень логистики; не достаточно развитая технологическая система по выращиванию овощных культур и складская инфрраструктура; низкая квалификация многих аграриев и фрермеров.

2. Предлагаем следующие пути решения: создание плодоовощных кластеров; восстановление и строительство новых, отвечающих современным требованиям хранилищ и перерабатывающих предприятий с использованием высокотехнологического и ресурсосберегающего оборудования; создание благоприятных взаимовыгодных условий между участниками плодовоовощного производства.

3. Важно государственное регулирование и стимулирование производства плодоовощной продукции: создание специальных кредитных линий для стимулирования производства плодоовощных культур, семян, саженцев, сбыта, хранения и переработки продукции, в т.ч. организации малой переработки овощей в местах производства с целью сокращения потерь сырья.

4. Для развития инновационной деятельности в плодоовощном секторе необходимы следующие мероприятия:
- в области сотрудничества науки с вузами, НИИ: создание интегрированной информационной системы, нацеленной на взаимоотношения между вузами, НИИ и производством;

- в области научно-технологического сопровождения: внедрение научно-обоснованной системы севооборотов, изучение и разработка приемов сохранения и воспроизводства плодородия почв;

- в области ресурсного обеспечения: рациональное использование ресурсов и экология производства; поддержка процессов внедрения и выведения новых сортов и гибридов плодоовощныхкультур; обмен опытом в области применения лучших практик земледелия, наращивания плодородия; оказание поддержки в обновлении материально-технической базы селекционных и семеноводческих хозяйствующих субъектов;

- в области инноваций, цифровизации и трансфрерта технологий: диффференцированное применение удобрений для плодоовощных культур в системе точного земледелия; технологии получения экологически чистой (органической) плодоовощной продукции, а также использование положительного опыта, унаследованного от старших поколений;

- в области экспортного потенциала: расширение маркетинговой политики; организация совместных торговых миссий и налаживание согласованности в контрактах между производителями государств-членов ЕАЭС и зарубежными партнерами и т.д.

5. Комплексное внедрение вышеприведенных мер должно ускорить перевод плодоовощных культур на инновационный путь развития, повысить производственные показатели плодоовощного сектора, эфффективное использование природных ресурсов. 


\section{Список литературы}

1 Акимбекова, Г.У. Современное состояние и потенциал развития сферы хранения и переработки плодоовощной продукции в Республике Казахстан / Г.У. Акимбекова, А.С. Сапаров, А.Б. Баймуханов, У.Р. Каскабаев // Проблемы агрорынка.- 2018.- №4.- С.125-133.

2 ВО3 определила норму потребления фруктов и овощей в день [Электронный реcypc].- 2016.- URL: http://www.normoflorin. ru/ voz-opredelila-normu-potrebleniya-fru (дата обращения: 17.06.2020).

3 В создании овощного кластера необходима поддержка республиканских органов [Электронный ресурс].- 2020. - URL: http:// www.zakon.kz/ 98035-v-sozdanii- ovoshhnogoklastera.html (дата обращения: 5.06. 2020).

4 Население Казахстана [Электронный реcypc].-2019.-URL:http://www.countrymeters.info/ ru/Kazakhstan (дата обращения: 5.02.2020).

5 О потреблении продуктов питания в домашних хозяйствах в Республике Казахстан в 2019 году [Электронный ресурс]. -2019. URL:http://www.kaz.zakon.kz/5019062-o-potreblenii-produktov-pitaniya-v.html (дата обращения: 5.02.2020).

6 Основные показатели работы промышленности РК за 2017г. [Электронный ресурс]. - 2018. -URL: http:// www.stat.gov.kz/ faces/ (дата обращения: 20.11.2018).

7 Своик П. Мясной провал в период / П Своик //Ведомости Казахстана.-2020.-23 марта.

8 Акимбекова, Г.У. Механизм формирования и функционирования отраслевых кластеров в сферах производства, хранения, переработки и сбыта сельскохозяйственной продукции (методические рекомендации) / Г.У. Акимбекова, А.Б. Баймуханов, У.Р. Каскабаев, М.С. Мухаджан.- Алматы, 2017.- 53 с.

9 Программа развития Жамбылской области на 2016-2020 годы [Электронный реcypc].- 2020.- URL: http://www.zhambyl.gov. kz/ ru/news/plan_meropriyatiy(дата обращения: 5.06.2020).

10 Мырзалиев Б.С. Қазақстан Республикасының агроөнеркәсіптік кешеніндегі инновациялық үдерістер: мәселелері және оларды шешу жолдары /Б.С. Мырзалиев, Е.Т. Абилкасимов, Л.Т. Тайжанов // Проблемы агрорынка. - 2020. - № 1. - Б.18-26.

11 Базарбаев А.О. Қазақстан Республикасының агроөнеркәсіптік кешенін дамыту мәселелері және оларды шешу жолдары
/А.О. Базарбаев, Б.К. Купешова // Проблемы агрорынка. - 2019. - № 3. - Б.42-48.

\section{References}

1 Akimbekova, G.U. Current state and development potential of storage and processing of fruit and vegetable products in the Republic of Kazakhstan / G.U. Akimbekova, A.S. Saparov, A.B. Baimukhanov, U.R. Kaskabayev // Problems of AgriMarket.- 2018.- No. 4. - P.125-133.

$2 \mathrm{WHO}$ has determined the rate of consumption of fruits and vegetables per day [Electronic resource]. - 2016. - URL: http://www. normoflorin.ru/voz-opredelila-normupotrebleniya-fru (date of access: 17.06.2020).

3 The creation of vegetable cluster requires support from the republican authorities [Electronic resource].- 2020.- URL: http://www.zakon. kz/98035- v- sozdanii-ovoshhnogo-klastera.html (date of access: 5.06.2020) ...

4 The population of Kazakhstan [Electronic resource]. -2019. -URL: http:// www. countrymeters.info/ru/Kazakhstan(date of access:5.02. 2020).

5 On consumption of food products in households in the Republic of Kazakhstan in 2019 [Electronic resource]. - 2019. - URL: http:// www. kaz.zakon.kz/ 5019062-o-potreblenii-pro-duktovpitaniya-v.html (date of access: 5.02. 2020).

6 Key performance indicators of the industry of the RK for 2017. [Electronic resource]. - 2018. -URL: http://www.stat.gov.kz/ faces / (date of access: 20.11.2018).

7 Svoik P. Meat failure in the period / P.Svoik/Nedomosti Kazakhstana.- 2020.- March 23.

8 Akimbekova, G.U. The mechanism of formation and functioning of sectoral clusters in spheres of production, storage, processing and marketing of agricultural products (guidelines) / G.U. Akimbekova, A.B. Baimukhanov, U.R. Kaskabayev, M.S. Muhajan.- Almaty, 2017 .- 53 p.

9 The development program of Zhambyl region for 2016-2020 [Electronic resource] .2020.- URL:http://www.zhambyl.gov.kz/ru/ news/ plan_meropriyatiy (date of access: 5.06 .2020 ).

10 Myrzaliyev B.S. Innovative processes in agro-industrial complex of the Republic of Kazakhstan: problems and ways of solution / B.S. Myrzaliyev, E.T. Abilkasimov, L.T.Taizhanov // Problems of AgriMarket.- 2020. - № 1. - P.18-26.

11 Bazarbaev A.O. Problems of agro-industrial complex developmentin the Republic of Kazakhstan and their solutions /A.O. Bazarbaev, B.K. Kupeshova // Problems of AgriMarket. 2019. - № 3. - P.42-48.

\section{Информация об авторах:}

Гриднева Елена Евгеньевна, кандидат экономических наук, доцент, профессор кафедры «Экономика и бизнес», Академия «Кайнар», Алматы, Казахстан, elengred@mail.ru, https://orcid.org/ 0000-0002-3279-2036

Калиакпарова Гульнар Шаймардановна, доктор PhD, заведующая кафедрой «Экономика и бизнес», Академия «Кайнар», Алматы, Казахстан, GK_2003@rambler.ru, https://orcid.org/0000-00021859-9774

Калманова Набира Майлановна, магистр экономики и бизнеса, старший преподаватель, Академия «Кайнар», Алматы, Казахстан, nabi241174@mail.ru, https://orcid.org/0000-0002-0510-092X 